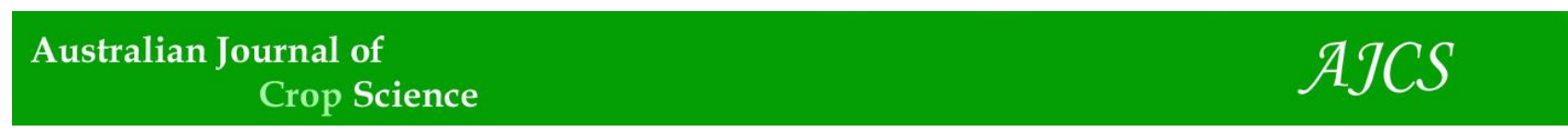

AJCS 11(11):1469-1473 (2017)

ISSN:1835-2707

doi: 10.21475/ajcs.17.11.11.pne685

\title{
Application of silicon sources in yam (Dioscorea spp.) micropropagation
}

\section{Filipe Almendagna Rodrigues ${ }^{1}$, Renata Alves Lara Silva Rezende ${ }^{1}$, Joyce Dória Rodrigues Soares ${ }^{1}$, Vantuil Antonio Rodrigues ${ }^{1}$, Moacir Pasqual ${ }^{1}$ and Sebastião de Oliveira e Silva ${ }^{2}$}

\author{
${ }^{1}$ Department of Agriculture, Federal University of Lavras, Lavras, Minas Gerais State, Brazil \\ ${ }^{2}$ Federal University of Recôncavo of Bahia, Cruz das Almas, Bahia State, Brazil
}

*Corresponding author: filipealmendagna@yahoo.com.br

\begin{abstract}
The addition of silicon is known to produce satisfactory results in several types of plant cultures. However, there are no reports on the effects of addition of silicon to yam (Dioscorea spp.) micropropagation culture medium. The objective of the present study was to evaluate the effects of different silicon concentrations and sources on the growth characteristics of yam plants cultivated in vitro. Three sources of silicon were tested: potassium silicate, calcium silicate, and sodium silicate, each at concentrations of $0.0,0.5,1.0$, and $2.0 \mathrm{mg} \mathrm{L}^{-1}$, in all possible combinations. The experimental design was entirely randomized in a $3 \times 4$ factorial scheme with four replicates and twelve plants per treatment. The $2 \mathrm{mg} \mathrm{L}^{-1}$ sodium silicate supplement yielded the highest number of leaves (7.0) whereas the $1 \mathrm{mg} \mathrm{L}^{-1}$ sodium silicate produced the longest shoots $(4.02 \mathrm{~cm})$. Calcium silicate and potassium silicate yielded the highest fresh weight $(0.2835 \mathrm{~g}$ and $0.2627 \mathrm{~g}$, respectively). Overall, silicon promotes better plant development, with calcium silicate yielding the highest fresh weight. For in vitro yam cultivation, sodium silicate concentrations ranging between $1-2 \mathrm{mg} \mathrm{L}^{-1}$ are ideal.
\end{abstract}

Keywords: phytotechnical analyses; silicates; tissue culture; vegetative propagation.

Abbreviations: ANOVA_analysis of variance, MS_Murashige and Skoog, SiCa_calcium silicate, SiK_potassium silicate, SiNa_sodium silicate

\section{Introduction}

Yams (Dioscorea spp.) are tuberous plant species with high agricultural potential. Containing high levels of thiamine, niacin, vitamins $\mathrm{A}$ and $\mathrm{C}$, carbohydrates, and starch and rich in calcium, iron, phosphorus, and B vitamins, yams provide beneficial nutrients. Importantly, yams contain high levels of vitamin B1, which is important for the growth of children, and vitamin B5, which strengthens the immune system. Thus, yams comprise a basic food source and can be utilized in agroindustry (Leonel et al., 2006).

In Brazil, yam cultivation is limited by a lack of healthy and vigorous propagative material. Micropropagation is proposed as a solution that can also reduce plantlet production time. One of the main applications of plant tissue culture, micropropagation comprises several methods for in vitro vegetative propagation and uses small propagules (Neto and Andrade 2011).

Micropropagation is highly important for agriculturally important plant species, especially when it is necessary to maintain the genotypic characteristics of the mother plant, precocity, homogeneity of the propagated material, control of environmental conditions, and production of disease-free plants. According to Santos et al. (2011), propagation by plant tissue cultivation enables large-scale production of plants with high agronomic quality in any season because it achieves the maximum utilization of the vegetative propagule in a short time period.

Silicon ( $\mathrm{Si}$ is the second most abundant element in the Earth's crust and has been the subject of several studies that demonstrated its beneficial effects for agriculture. Contributing both to plant growth and crop yield, Si helps increase the tolerance of numerous plant species to biotic and abiotic stresses (Hattori et al., 2005; Gunes et al., 2007).

In plants, $\mathrm{Si}$ is considered a beneficial mineral element. Although it is not regarded as an essential plant nutrient, Si has been widely studied (Epstein, 2004). Epstein (2001) concludes that $\mathrm{Si}$ accumulates in plants at the same level as that of macronutrients such as calcium, magnesium, and phosphorus. Furthermore, Sahebi et al. (2016) reports positive effects of $\mathrm{Si}$ on plant growth and development.

$\mathrm{Si}$ indirectly increases photosynthetic capacity, decreases transpiration, and improves mechanical resistance of the cell (Camargo et al., 2007). Additionally, Si produces more erect plants, increases pest resistance, decreases toxic effects of B, $\mathrm{Mn}$, and $\mathrm{Fe}$, among other elements, and increases nutrient absorption and metabolism (Lana et al., 2003; Gunes et al., 2007).

Previous reports suggest that supplementing plant culture media with $\mathrm{Si}$ improves the morphogenetic potential of plant cells, tissues, and organs. A few studies showed that adding $\mathrm{Si}$ to the culture medium promoted callus production, seedling regeneration, and root induction, and improved seedling physiological, morphological, and anatomical characteristics (Sivanesan and Park, 2014).

Reports of satisfactory in vitro results for $\mathrm{Si}$ supplementation include studies of ornithogalum ( $\mathrm{Ziv}$ et al., 2010), begonia (Lim et al., 2012), water reed (Mathé et al., 2012), rice (He et al., 2013), pear (Reed et al., 2013), orchids (Soares et al., 2011; Soares et al., 2012; Colombo et al., 2016), banana plants (Asmar et al., 2013a, b), ajuga (Sivanesan and Jeong, 2014), and anthurium (Dias et al., 
Table 1. Effect of silicon sources on the number of roots on yam plants (Dioscorea spp.) after $90 \mathrm{~d}$ cultivation in vitro.

\begin{tabular}{lc}
\hline Silicon source & Number of roots \\
\hline Sodium silicate & $2.50 \mathrm{a}$ \\
Potassium silicate & $2.89 \mathrm{a}$ \\
Calcium silicate & $3.00 \mathrm{a}$ \\
\hline $\mathrm{CV}(\%)$ & 30.34 \\
\hline
\end{tabular}

Means followed by the same letter do not significantly differ from each other according to the Scott-Knott test at a $5 \%$ significance level.

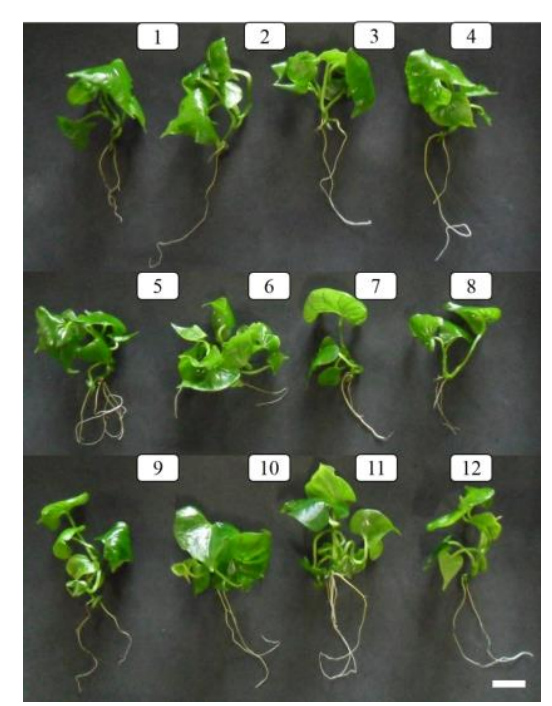

Fig 1. Effects of different silicon sources and concentrations on the in vitro development of yam (Dioscorea spp.): 1 ) absence (0.0 $\mathrm{mg} \mathrm{L}^{-1}$ ) of potassium silicate; 2) $0.5 \mathrm{mg} \mathrm{L}^{-1}$ potassium silicate; 3) $1.0 \mathrm{mg} \mathrm{L}^{-1}$ potassium silicate; 4) $2.0 \mathrm{mg} \mathrm{L}^{-1}$ potassium silicate; 5) absence $\left(0.0 \mathrm{mg} \mathrm{L}^{-1}\right)$ of calcium silicate; 6) $0.5 \mathrm{mg} \mathrm{L}^{-1}$ calcium silicate; 7) $1.0 \mathrm{mg} \mathrm{L}^{-1}$ calcium silicate; 8) $2.0 \mathrm{mg} \mathrm{L}^{-1}$ calcium silicate; 9) absence $\left(0.0 \mathrm{mg} \mathrm{L}^{-1}\right)$ of sodium silicate; 10) $0.5 \mathrm{mg} \mathrm{L}^{-1}$ sodium silicate; 11) $1.0 \mathrm{mg} \mathrm{L}^{-1}$ sodium silicate and 12) $2.0 \mathrm{mg} \mathrm{L}^{-1}$ sodium silicate. Cultivation time: $90 \mathrm{~d}$. $\mathrm{Bar}=2 \mathrm{~cm}$.

Table 2. Effects of silicon sources on the fresh weight of yam plants (Dioscorea spp.) after $90 \mathrm{~d}$ cultivation in vitro.

\begin{tabular}{lc}
\hline Silicon source & Plant fresh weight $(\mathrm{g})$ \\
\hline Sodium silicate & $0.2234 \mathrm{~b}$ \\
Potassium silicate & $0.2835 \mathrm{a}$ \\
Calcium silicate & $0.2627 \mathrm{a}$ \\
\hline $\mathrm{CV}(\%)$ & 22.46 \\
\hline
\end{tabular}

Means followed by the same letter do not significantly differ from each other according to the Scott-Knott test at a $5 \%$ significance level.

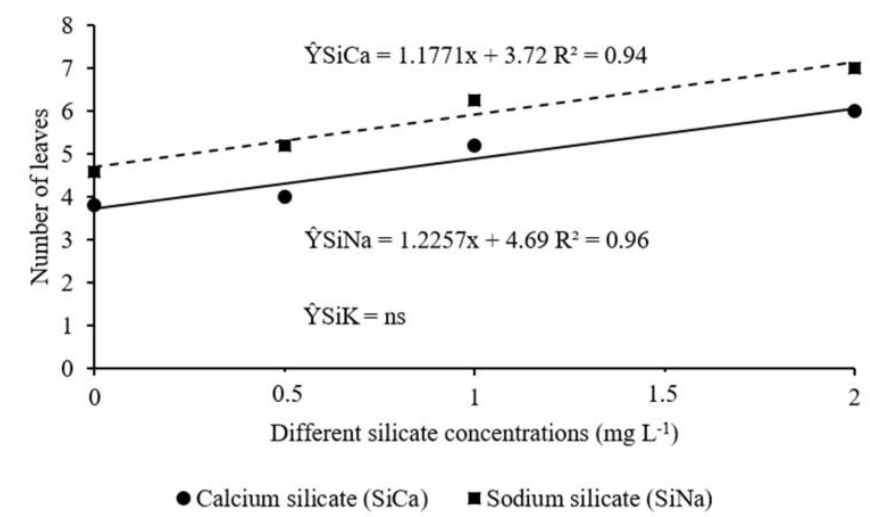

Fig 2. Number of leaves of yam (Dioscorea spp.) plants cultivated in vitro with different silicate concentrations. Legend: $\mathrm{ns}=$ nonsignificant. 


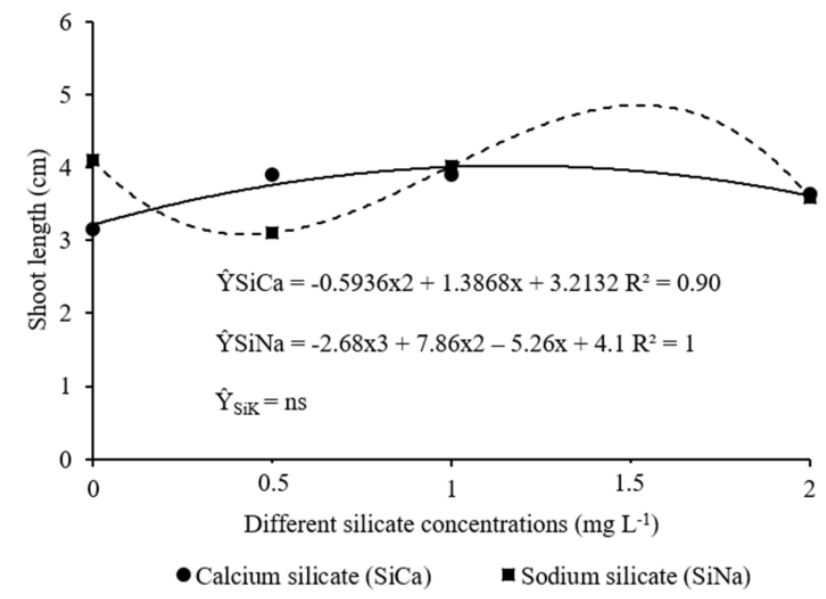

Fig 3. Shoot length in yam plants (Dioscorea spp.) cultivated in vitro under different silicate concentrations. Legend: ns $=$ nonsignificant.

2014). However, no study has reported the effects of $\mathrm{Si}$ addition to yam micropropagation culture media. Therefore, the aim of the present study was to evaluate the effect of different concentrations and sources of silicon on the growth characteristics of yam plants cultivated in vitro.

\section{Results and Discussion}

Overall, there was a significant effect of the silicon sources and concentrations on the number of leaves and shoot length. Root number differed across the silicate concentrations whereas plant fresh weight differed across the silicate sources. Figure 1 shows the development of yam plants under different silicate concentrations after ninety days of in vitro cultivation.

\section{Number of leaves}

The addition of $2 \mathrm{mg} \mathrm{L}^{-1}$ sodium silicate resulted in the highest number of leaves in yam plants (Fig. 2). This finding concurs with that reported by Braga et al. (2009) who observed an increase in the number of leaves in strawberry trees (Fragaria $\times$ ananassa) with sodium silicate supplementation of MS medium. There were no significant differences in the number of leaves across potassium silicate concentrations (Fig. 2). Asmar et al. (2013b), who evaluated the effect of different potassium silicate concentrations on the in vitro growth of the banana tree cultivar Grande Naine, also found no significant differences in the number of leaves. However, Asmar et al. (2011) did observe significant differences in the number of leaves in plantlets of banana tree cultivar Maçã grown on media containing sodium silicate, potassium silicate, and calcium silicate.

Pasqual et al. (2011) reported that in two orchid species (native and hybrid), the number of leaves decreased as the calcium silicate concentration increased. This observation may be explained by the fact that an excess of all nutrients causes a nutritional imbalance and leads to deficiencies or overaccumulation of nutrients (Malavolta, 2006).

\section{Shoot length}

All silicate sources and concentrations, except for potassium silicate, had a significant effect on shoot length. Sodium silicate at $1.95 \mathrm{mg} \mathrm{L}^{-1}$ yielded the longest shoots (Fig. 3). Soares et al. (2011) evaluated the effect of sodium silicate and potassium silicate on the in vitro cultivation of an orchid (Cattleya loddigesii) and reported longer shoots (relative to the control) with both potassium silicate and sodium silicate added to the medium. Asmar et al. (2013b) tested distinct silicon sources on the in vitro cultivation of the banana tree cultivar Grande Naine and found no significant differences in shoot length.

\section{Number of roots}

There were no significant differences in number of roots across silicate concentrations and sources (Table 1). Similarly, Asmar et al. (2013b) found no significant difference in root number for any silicon sources they used. Colombo et al. (2016) found no significant effect of silicon sources and concentrations on the in vitro growth of an orchid (Cattleya forbesii). However, Soares et al. (2011) reported a positive effect of sodium silicate on root number.

\section{Plant fresh weight}

The fresh weights were relatively higher for plants supplemented with calcium silicate $(0.2835 \mathrm{~g})$ and potassium silicate (0.2627 g; Table 2). Romero-Aranda et al. (2006) also found higher fresh weights in tomato supplemented with potassium silicate. Asmar et al. (2013b) concluded that the capacity of plants to absorb and accumulate silicon varies depending on element availability and plant species. Lim et al. (2012) studied the effect of silicon on two begonia (Begonia semperflorens) cultivars raised in vitro and observed that potassium silicate supplementation resulted in increased plant fresh weight.

\section{Materials and Methods}

\section{Location}

The experiment was conducted in the Laboratory of Tissue Culture in the Department of Agriculture at the Federal University of Lavras in Lavras, Minas Gerais, Brazil. 


\section{Plant material and experimental conditions}

Nodal segments with a meristem approximately $1 \mathrm{~cm}$ in size, originating from yam plants (Dioscorea spp.) already established in vitro were inoculated in test tubes $(25 \times 150$ $\mathrm{mm}$ ) containing MS medium (Murashige and Skoog, 1962) with $30 \mathrm{~g} \mathrm{~L}^{-1}$ sucrose (SIGMA $^{\circledR}$, Saint Louis, USA). The $\mathrm{pH}$ of the medium was adjusted to 5.8 before solidification with $5.5 \mathrm{~g} \mathrm{~L} \mathrm{~L}^{-1}$ agar (HIMEDIA ${ }^{\circledR}$, Mumbai, India), and then autoclaved at $121^{\circ} \mathrm{C}$ and $101.3 \mathrm{kPa}$ for $20 \mathrm{~min}$. Three silicon sources (SIGMA ${ }^{\circledR}$, Saint Louis, USA) were tested: potassium silicate, calcium silicate, and sodium silicate at concentrations of $0.0,0.5,1.0$, and $2.0 \mathrm{mg} \mathrm{L}^{-1}$ in all possible combinations. The segments were inoculated into test tubes containing $15 \mathrm{~mL}$ MS medium with the respective sources and concentrations of silicate, then the vessels were maintained in a growth chamber at $25 \pm 2{ }^{\circ} \mathrm{C}$, an average irradiance of $52.5 \mu \mathrm{mol} \mathrm{m} \mathrm{m}^{-2} \mathrm{~s}^{-1}$, and a photoperiod of $16 \mathrm{~h}$.

\section{Phytotechnical analyses}

The following variables were measured: number of leaves, shoot length $(\mathrm{cm})$, number of roots, and plant fresh weight (g).

\section{Experimental design and statistical analysis}

The experimental design was entirely randomized and consisted of a $3 \times 4$ factorial scheme with four replicates and twelve plantlets per treatment. Raw data were subjected to ANOVA (analysis of variance). Means of qualitative results were compared using the Scott-Knott test at a 5\% significance level, and the quantitative data were analyzed by polynomial regression using the SISVAR statistical software (Ferreira, 2011).

\section{Conclusion}

Silicon promotes and improves plant growth and development. Although calcium silicate increases the fresh weight of yam plants (Dioscorea spp.), $2 \mathrm{mg} \mathrm{L}^{-1}$ sodium silicate is optimal for their in vitro cultivation.

\section{Acknowledgments}

The authors thank National Council for Scientific and Technical Development (CNPq) and Foundation for Support of Research in Minas Gerais (FAPEMIG) for their financial support, and Coordination of Improvement of Higher Education Personnel (CAPES) for providing a fellowship for the present study.

\section{References}

Asmar SA, Pasqual M, Rodrigues FA, Araujo AG, Pio LAS, Silva SO (2011) Fontes de silício no desenvolvimento de plântulas de bananeira 'Maçã' micropropagadas. Cienc Rural. 41:1127-1131.

Asmar S, Castro E, Pasqual M, Pereira F, Soares J (2013a) Changes in leaf anatomy and photosynthesis of micropropagated banana plantlets under different silicon sources. Sci Hort. 161:328-332.

Asmar SA, Pasqual M, Araujo AG, Silva RAL, Rodrigues FA, Pio LAS (2013b) Morphophysiological characteristics of acclimatized 'Grande Naine' banana plants in response to in vitro use of silicon. Semin Cien Agrar. 34:73-81.
Braga FT, Nunes CF, Favero AC, Carvalho JG, Castro EM (2009) Características anatômicas de mudas de morangueiro micropropagadas com diferentes fontes de silício. Pesq Agropec Bras. 44:128-132.

Camargo MS, Korndörfer GH, Pereira HS (2007) Solubilidade do silício em solos: influência do calcário e ácido salicílico aplicados. Bragantia. 66:637-647.

Colombo RC, Favetta V, Faria RT, Andrade FA, Melem VM (2016) Response of Cattleya forbesii orchid to increasing silicon concentrations in vitro. Rev Caatinga. 29:18-24.

Dias GMG, Soares JDR, Pasqual M, Silva RAL, Rodrigues LCA, Pereira FJ, Castro EM (2014) Photosynthesis and leaf anatomy of Anthurium cv. Rubi plantlets cultured in vitro under different silicon $(\mathrm{Si})$ concentrations. Aust $\mathrm{J}$ Crop Sci. 8:1160-1167.

Epstein E (2001) Silicon in plants: facts vs. concepts. In: Datnoff LE, Snyder GH, Korndörfer GH (eds) Silicon in agriculture. Elsevier, Amsterdam. 1-15.

Epstein E, Bloom AJ (2004) Nutrição mineral de plantas: princípios e perspectivas. 2nd edn. Londrina, PR: Planta.

Ferreira DF (2011) SISVAR: A computer statistical analysis system. Cienc Agrotec. 35:1039-1042.

Gunes A, Inal A, Bagci EG, Coban S (2007) Siliconmediated changes on some physiological and enzymatic parameters symptomatic of oxidative stress in barley grown in sodic-B toxic soil. J Plant Physiol. 164:807-811.

Hattori T, Inanaga S, Haraki H, Morita S, Luxova M, Lux A (2005) Application of silicon enhanced drought tolerance in Sorghum bicolor. Physiol Plant. 123:459-466.

He C, Wang L, Liu J, Liu X, Li X, Ma J (2013) Evidence for "silicon" within the cell walls of suspension-cultured rice cells. New Phytol. 200:700-709.

Lana RMQ, Korndörfer GH, Zanão-Júnior LA, Silva AF (2003) Efeito do silicato de cálcio sobre a produtividade e acumulação de silício no tomateiro. Biosci J. 19:15-20.

Leonel M, Mischan MM, Pinho SZ (2006) Efeitos de parâmetros de extrusão nas propriedades físicas de produtos expandidos de inhame. Cienc Tecnol Aliment. 26:459-464.

Lim MY, Lee EJ, Jana S, Sivanesan I, Jeong BR (2012) Effect of potassium silicate on growth and leaf epidermal characteristics of begonia and pansy grown in vitro. Kor $\mathbf{J}$ Hort Sci and Technol. 30:579-585.

Malavolta E (2006) Manual de nutrição mineral de plantas. Editora Agronômica Ceres, São Paulo, São Paulo.

Mathé C, Mosolygo A, Suranyi G, Beke A, Demeter Z, Toth VR (2012) Genotype and explants-type-dependent morphogenesis and silicon response of common reed (Phragmites australis) tissue cultures. Aquat Bot. 97:5763.

Murashige T, Skoog F (1962) A revised medium for rapid growth and bioassays with tobacco tissue cultures. Physiol Plant. 15:473-497.

Neto SPS, Andrade SRM (2011) Cultura de tecidos vegetais: princípios e aplicações. In: Faleiro FG, Andrade SRM (eds) Biotecnologia: estado da arte e aplicações na agropecuária. Embrapa Cerrados, Planaltina. 411-434.

Pasqual M, Soares JDR, Rodrigues FA, Araujo AG, Santos RR (2011) Influência da qualidade de luz e silício no crescimento in vitro de orquídeas nativas e híbridas. Hortic Bras. 29:324-329.

Reed BM, Wada S, Denoma J, Niedz RP (2013) Mineral nutrition influences physiological responses of pear in vitro. In Vitro Cell Dev Biol - Plant. 49:699-709. 
Romero-Aranda M, Jurado O, Cuarteto J (2006) Silicon alleviates the deleterious salt effect on tomato plant growth by improving plant water status. J Plant Physiol. 163:847855.

Sahebi M, Hanafi MM, Parisa A (2016) Application of silicon in plant tissue culture. In Vitro Cell Dev Biol Plant. 52:226-232.

Santos ES, Cazé Filho J, Macêdo LS (2001) Propagação vegetativa do inhame (Dioscorea spp.) por métodos convencionais e biotecnológicos. EMEPA-PB/Banco do Nordeste.

Sivanesan I, Park SW (2014) The role of silicone in plant tissue culture. Front Plant Sci 5:1-4.
Sivanesan I, Jeong BR (2014) Silicon promotes adventitious shoot regeneration and enhances salinity tolerance of Ajuga multiflora Bunge by altering activity of antioxidant enzyme. Sci World J. 2014:1-10.

Soares JDR, Pasqual M, Rodrigues FA, Villa F, Araujo AG (2011) Fontes de silício na micropropagação de orquídea do grupo Cattleya. Acta Sci Agron. 33:503-507.

Soares JDR, Pasqual M, Araujo AG, Castro EM, Pereira FJ, Braga FT (2012) Leaf anatomy of orchids micropropagated with different silicon concentrations. Acta Sci Agron. 34:413-421.

Ziv M (2010) Silicon effects on growth acclimatization and stress tolerance of bioreactor cultured Ornithogalum dubium plants. Acta Hort. 865:29-36. 